\title{
Narratives of Sámi School History in Finland: The Histories of Assimilation Made Visible
}

\author{
Jukka Nyyssönen
}

\begin{abstract}
This article analyses narratives that have been produced about the Sámi school experience in Finland. The sources consist of studies in Sámi school history and history of education in Finland, as well as in pedagogical studies made since the 1980s, comparing the narratives found in each case. The narrative of assimilation dominates the field for good, historically verifiable reasons. This genre of studies is contextualised and discussed in relation to the national development of Sámi tuition, the Sámi movement and international studies of history of education. The late emergence of this genre in Finland is evident in the approaches to bringing these affecting and usable histories to light, while the multiplicity of the historical voices in this field is only now emerging.
\end{abstract}

Keywords • Sámi school history, Finland, narratives, assimilation, historiography, history of education

\section{Introduction}

The aim of this historiographical article is to analyse and discuss narratives produced in the research of Sámi school history and history of education in Finland. For a start, school history and history of education are important sub-genres in Sámi research. This is not only due to the ample number of exciting academic findings to be unveiled in this recent field of study, or because of its ethnopolitical importance, but also because of the foundational significance that school history possesses for individual pupils. This makes the task ahead a difficult one. There has been extensive coverage of Sámi school experiences recently in Sámi medias, ${ }^{1}$ but there are still many former pupils who do not wish to be confronted by a past that was, at worst, traumatising. Nonetheless, and stressing the multi-levelled importance of this topic, I wish to look at Finnish studies of Sámi school history, partly in order to illustrate the numerous aspects and potentials encapsulated in studies of this topic.

Sámi school history in Finland is a small ${ }^{2}$ but growing multi-disciplinary field of scholarly inquiry that has evolved from an older interest in school histories written

1 YLE Sápmi, "Äidinkielensä vuosikymmeniksi menettänyt Seija: 'Vasta viisikymppisenä päästin tuskan ulos sisältäni' [Seija lost her mother tongue for several decades: 'Only in my 50s could I let the pain out']," http://yle.fi/uutiset/3-9231306, accessed 16.10.2016.

2 The genre boasted 10 monographs in 2014, but the interest in Sámi educational issues per se extends back to nineteenth-century "Lappological" studies. Pigga Keskitalo, Veli-Pekka Lehtola and Merja Paksuniemi, "Johdatus saamelaisten kansanopetuksen ja koulunkäynnin historiaan [An introduction to the history of Sámi education and school attendance]," in Saamelaisten kansanopetuksen ja koulunkäynnin historia Suomessa [The history of Sámi education and school attendance in Finland], ed. Pigga Keskitalo, Veli-Pekka Lehtola and Merja Paksuniemi (Turku: Siirtolaisuusinstituutti, 2014), 20-21.

Jukka Nyyssönen is a researcher at the Tromsø University Museum, the University of Tromsø - The Arctic University of Norway.

Email:jukka.kalervo@uit.no 
by amateur and professional scholars alike and published in municipal histories, for example, to more ambitious histories of Sámi education. This genre boasts a wider thematic scope that extends from the structures and ideologies supporting schools at a local level to a more stringent contextualising and theoretical grasp in analysing, for example, the power structures and asymmetries reproduced in the school institution. ${ }^{3}$ The choice of research material in this article covers studies of Sámi school history/history of education and the most significant recent studies of Sámi history dealing partly, but not solely, with aspects of Sámi school history. The range of studies selected varies from master's dissertations to doctoral theses and scholarly monographs dating from around the late 1980s (publication of the book by Marjut Aikio, presented later on) to the present day. The selection has been undertaken on the basis of providing a sufficiently wide coverage of the theme in order to be able to grasp the narrative strategy: the aim is to study the most recent wave of research, due to a contemporary pluralisation of the field. This pluralisation has been due to the entrance of educationalists into this field of research, posing a research political challenge to traditionally less politicised studies by historians; a comparison is undertaken of these two disciplines. I shall review six studies by six historians (Unconventionally, this sample includes my own studies on the topic) and six pedagogical studies, focusing on the political challenge of the research and the different narrative strategy of the educationalists.

No study of this kind has been made on this material or from this perspective, but some historiographical work has been inspirational and is used here as a foundation for this study. In studies of the historiography of colonial education, a strong ideological foundation and an early, or timely, critical decolonising turn and ideological polarisation are detectable. Marxist criticism of education as a tool of empire-building, for example, emerged in earnest in the UK during the 1970s. These studies have also revealed ideologised debates of the gains to be made and problems embedded in colonial education. ${ }^{4}$ As a sub-discipline of Sámi studies, emerging as part of a wider ethnopolitical awakening among the Sámi in Finland and a connected need to re-interpret and self-interpret their history, as well as a more general democratisation of historical inquiry and the choice of sources, ${ }^{5}$ the new genre of historical and pedagogical studies of Sámi school history strongly resembles the anti-colonial phase of research relating to colonial education, with its stress on assimilation. A focus on shortcomings and cultural insensitivity has led to the dominance of victim narratives. More recently, studies of colonial education have engaged in the issues of indigenous support and gains in schooling ${ }^{6}$ or, in the post-colonial scholarly production, in the discussion of a culturally sustainable education as a source of native

3 The distinction between school history and history of education/educational history is not clear in most Finnish research in this discipline. The terms are intermingled and "school history" is pursued with as high scholarly aims as history of education. See e.g. Keskitalo, Lehtola and Paksuniemi (2014), 13-20.

4 Clive Whitehead, “The Historiography of British Imperial Education Policy, Part I: India," History of Education 34, no. 3, (2005), 315-18.

5 Veli-Pekka Lehtola, “'The Right to One’s Own Past:' Sámi Cultural heritage and Historical Awareness," in The North Calotte, Perspectives on the Histories and Cultures of Northernmost Europe, ed. Maria Lähteenmäki, Päivi Pihlaja, Publications of the Department of History 18 (Helsinki/Inari: University of Helsinki, Kustannus-Puntsi, 2005a), 86-87, 90-91.

6 Whitehead (2005), passim; Alan Williamson, "Decolonizing Historiography of Colonial Education: Processes of Interaction in the Schooling of Torres Strait Islanders," International Journal of Qualitative Studies in Education 10, no. 4 (1997), 408-11 et passim. 
health, achievement and empowerment. ${ }^{7}$ It is argued that the Finnish studies belong in the critical vein and lack to some extent the international focus on the potential historical gains of receiving an education. ${ }^{8}$

\section{Theory and research questions}

Since the focus is on the construction of texts and their desired effects, the overarching theoretical approach is to view research as a discursive practice: rather than strictly reflecting reality, science in general and research in particular are entangled with social and political relations, involving an ideological and discursive construction of the object of its enquiry. Knowledge produced comprises not mere facts, but emergent property between and among differently-positioned individuals, including the researcher, which may be approached discursively and analysed. Scientific discourse has produced many competing 'truths' about different groups of people, for numerous purposes: to classify and distinguish differences within colonial populations, for example. ${ }^{9}$ Here, the focus is on the narrative strategy which the authors in focus have utilised in their production and in different disciplines, and on what that reveals of the intended politics.

With regard to the analysis of the narratives, I have relied on the typology of Jörn Rüsen, who considers that narratives mobilise the past in a way that makes the past understandable and the future possible to form. Rüsen is interested in the functions of the different narratives, what the narrative produced by a scholar does, in addition to what it is saying. The point of departure for Rüsen is the narrative's relation to tradition, and the function the tradition is intended to serve in the society that was contemporaneous to the writing historian. This makes it possible to study different research political orientations in Pedagogy and History. Rüsen firstly distinguishes narratives of tradition, which build continuity from the past and serve as a legitimation of contemporaneous identities and self-understandings. Secondly, exemplary narratives fortify abstract rules and principles in society and use history as a "mentor of life." Thirdly, critical narratives create distance from tradition, which is deemed unwanted, pointing out a new and better action for the future. These counter-narratives strive to substitute one existing structure with another. A genetic narrative takes heed of historical change as such, without any normative judgment on the change, and reflects on the need for a change in politics in tandem with actual historical change. ${ }^{10}$ This last-mentioned stance resonates well with traditional epistemological

7 Malinda S. Smith, "Situating Indigenous Education in Canada," and Waziyatawin (Angela Wilson), "Indigenous knowledge, anticolonialism and empowerment," both in Essays on Transforming the Academy, Indigenous Education, Knowledge and Relations, ed. Malinda S. Smith (Edmonton: University of Alberta, 2013), https://www.ualberta.ca/-/media/D2916F31E07E43B5BFF8AF3FE2923920 (accessed August 30, 2018).

8 See, however the work of Ritva Kylli, highlighting this aspect briefly. Ritva Kylli, "Utsjoen kristillinen kansanopetus Laiti-suvun edustajien kautta kuvattuna, [The Christian education in Utsjoki depicted through Laiti-kin]," in Saamelaisten kansanopetuksen ja koulunkäynnin historia Suomessa, ed. Pigga Keskitalo, Veli-Pekka Lehtola, and Merja Paksuniemi (Turku: Siirtolaisuusinstituutti, 2014), 117.

9 Yasmin Gunaratnam, Researching Race and Ethnicity: Methods, Knowledge and Power (London: Sage Publications, 2003), 7-9.

10 Jörn Rüsen, "Tradition: A Principle of Historical Sense-Generation and Its Logic and Effect in Historical Culture," History \& Theory 51, no. 4 (2012), 51-53; see also Jan Heiret, Teemu Ryymin and Svein Atle Skålevåg, "Innledning," in Fortalt fortid: Norsk historieskriving etter 1970, ed. Jan Heiret, Teemu Ryymin, and Svein Atle Skålevåg (Oslo: Pax Forlag, 2013), 28. 
and hermeneutical stances in the study of History, aiming for a sympathetic understanding of the object of study. It will be argued that this approach still has some merit and usage value, but on its own it has come to a crisis in the field of Sámi studies, which is becoming increasingly instrumental and constructing its own critical narratives.

In what follows, I shall ponder the following questions: how are the narratives of Sámi school history constructed? On what kind of historical background or experience do they build? How do the narratives produced under the new instrumental paradigm differ from the narratives produced by historians? How might these differences be explained? Do the different disciplines have any common ground in the knowledge production of the history of Sámi education? Finally, the scholarly production is discussed in the context of recent developments in the Sámi movement in Finland.

\section{Sámi school history in Finland: General outlines}

Recent Finnish studies on school history and history of education have been written against a back-drop of narratives of Finnish education as a successful institution, becoming world-famous for producing top results in PISA (Programme for International Student Assessment) investigations, and being a significant factor behind the miracle of "Nokia Finland" (which is now in crisis). Even though this narrative has been articulated mostly in the media, there are also examples of such narratives constructed by historians, ${ }^{11}$ in response to neo-liberalist and market-oriented views on education, for example. There are also examples of less triumphalist views on the matter that also highlight problematic aspects of the school institution. ${ }^{12}$

There is no doubt about the national importance of the institution, though. The research stresses univocally the general importance of the institution in the nation building of Finland. Depending on national imperatives and transforming according to the perceived needs of the era, the school institution has stood in service for the genesis and survival of the nation, folk and newly-independent state, as well as in conveying to pupils the 'right' kind of Christian, moral and national identity. The folk school has been a means of creating unity as a nation against internal and external threats. The school has built up the economic competitiveness of the nation and catered for an efficient allocation of the labour force. National imperatives were adjusted somewhat after the Second World War, when sustaining and fulfilling the project of a (good) welfare state became paramount, with equality as one of its corner-stones, as well as the production of active and critical citizens capable of questioning foreign, anti-democratic impulses. Lately, Finnish schools have struggled with and resisted the neo-liberal impulses of international competitiveness. ${ }^{13}$

The Finnish national discourse on school and education is a malleable, transformable and truly constitutive and strong discourse, articulated according to changing national imperatives. The reigning ideal, (the production of) national unity, has been

11 Henrik Meinander, Suomen historia: Linjat, rakenteet, käännekohdat [The history of Finland: Lines, structures, turning points] (Helsinki: WSOY, 2006), 240-41.

12 Pauli Kettunen and Hannu Simola, eds., Tiedon ja osaamisen Suomi: Kasvatus ja koulutus Suomessa 1960-luvulta 2000-luvulle [Finland of knowledge and know-how: Education and schooling in Finland from 1960s to 2000s] (Helsinki: SKS, 2012), passim.

13 Kettunen and Simola (2012), passim. 
to some extent augmented by aspects of plurality that are sometimes articulated as multiculturalism. This has been done in the name of the needs of the allocation of the labour force, or because of emergent groups claiming a voice not necessarily sharing the identities produced within the institution, the Sámi being one of them. Since the discourse is a strong one, questions of Sámi as a language of tuition and of the survival of Sámi culture have appeared less significant and less pressing from a national point of view. ${ }^{14}$

As far as Sámi school history is concerned, during the late nineteenth century in the Sámi home area in Finland there was at least one school where teaching was given in Sámi, in Outakoski. ${ }^{15}$ The establishment of folk schools (the decree on 1866) resulted in a relatively late and incomplete introduction of the school network to areas populated by the Sámi from the 1880s onwards. One early-emerging aim was to prolong the education offered to pupils by building schools with dormitories, which became standard in the schools situated in the few population centres in the Sámi home area. Prior to the Second World War, itinerant catechist teaching provided tuition for pupils in remote areas; school legislation demanded that education be provided in schools only for those living less than five kilometres from a school. The Finnish education policy advocated the use of Sámi as a language in teaching, at least in principle: using Sámi as a language of tuition in schools was never forbidden and developing it was possible and sometimes even articulated, but in practice nothing was done to arrange for teaching in Sámi. Initiatives to secure Sámi educational rights were thus not put into effect. ${ }^{16}$

In general and in practice, the teaching available during the 1920s and 1930s did not reach all the potential pupils from the relevant age-cohorts in the Sámi home area, which was a factor in sustaining a command of Sámi languages in some agegroups and in some parts of the region. Both the short duration of the education on offer and the catechist teachers' use of the Sámi languages (not counting Skolt Sámi) sustained the overall command of Sámi languages. ${ }^{17}$

Following shorter and longer breaks in education during war time, the 1940 s and 1950s were marked by the end of catechist teaching and a consolidation of the folk school network; accommodation in dormitories or in another family's home was generally the case for children from peripheral parts of the Sámi home area. Now the entire age-cohorts were to receive a full education and the school dormitories were intended to make this possible. ${ }^{18}$ The cultural adjustment for Sámi children coming

14 Jukka Nyyssönen, "Suomalainen koululaitos ja saamelaiskysymys [The Finnish school institution and the Sámi question]," in Saamelaisten kansanopetuksen ja koulunkäynnin historia Suomessa, ed. Pigga Keskitalo, Veli-Pekka Lehtola, and Merja Paksuniemi (Turku: Siirtolaisuusinstituutti, 2014a), 170-71 et passim.

15 Otso Kortekangas has found indications of Sámi being used as a language of teaching in another school as well. Otso Kortekangas, Tools of Teaching and Means of Managing: Educational and Sociopolitical Functions of Languages of Instruction in Elementary Schools with Sámi Pupils in Sweden, Finland and Norway 1900-1940 in Cross-National Perspective (Turku: Iloinen tiede, 2017), 126.

16 Kortekangas (2017), 125ff et passim; Veli-Pekka Lehtola, Saamelaiset suomalaiset: Kohtaamisia 1896-1953 [The Sámi Finns: Encounters 1896-1953] (Helsinki: SKS, 2012), 82-99; Jukka Nyyssönen, "Saamelaisten kouluolot 1900-luvulla [Sámi school conditions in the twentieth century]," in Saamelaisten kansanopetuksen ja koulunkäynnin historia Suomessa, ed. Pigga Keskitalo, Veli-Pekka Lehtola, and Merja Paksuniemi (Turku: Siirtolaisuusinstituutti, 2014b), 64-70.

17 E.g. Nyyssönen (2014b), 66-67.

18 Nyyssönen (2014b), 66-72. 
from the peripheries, perhaps even from migratory lives, has always been big. ${ }^{19}$ This exposure created a generation of children with defects in their command over the Sámi languages. While perceptions in the public sphere and the national and Lapland media were mostly positive towards the education of the Sámi, as well as the dormitories, Sámi protests about the school institution lacking cultural sensitivity were already being heard during this period. ${ }^{20}$

During the 1970s, numerous Sámi pupils continued to attend schools with dormitories, although the scope of this type of accommodation was starting to diminish. A few Sámi teachers (e.g. Pekka Lukkari) worked and taught partly in Sámi, but mostly in Finnish, and worked on and published Sámi teaching materials. Due to a generation shift in the Sámi movement, the protests grew sharper, attacking the existence of the dormitories, the lack of Sámi substance in school education and shortcomings in teaching Sámi as a language to pupils. The first committees, with a Sámi majority as experts, and the Sámi Delegation (est. 1972) began to address these education issues. The aims of the protests and the efforts of the formal representatives were to ensure the survival and development of the Sámi culture. ${ }^{21}$

The work on these education issues achieved tangible results from the 1980s onwards. Before this, the work suffered from a chronic misplacement of teachers with the command of a Sámi language and a lack of teaching materials in Sámi languages. ${ }^{22}$ Within the Sámi movement, a strong interest group appeared at this time: Sámi teachers, who coupled schooling issues with the fate of the Sámi languages and culture. Much was at stake for this group and the discourse they launched bordered on alarmist, as well as guilt-tripping those who did not share their worries. At the same time the various Sámi languages were, and still are, struggling to survive. ${ }^{23}$

The Sámi movement had progressed in its ethnopolitics: it was no longer only the experience of educational inequality and the defects in access to education which were protested against, but also the inherently problematic aspects of Finnish ideas of equality produced in the school institution. These did not resonate with the Sámi minority needs and did not match the Sámi identities constructed during this era. Protests concerning the lack of support for the Sámi language and Sámi culture were of an older date, but they continued to be voiced. Whether it was an achievement on the part of the Finnish school system, a Sámi reaction to the system or a political innovation on the part of the Sámi themselves, this form of active and critical citizenship targeted school administration on many levels throughout the 1980s and 1990s. The engagement of sections of the Sámi Delegation/Parliament helped to create consistency in this work. ${ }^{24}$

19 Ritva Kylli, Kirkon ja saamelaisten kohtaaminen Utsjoella ja Inarissa 1742-1886 [The encounter between the church and the Sámi in Utsjoki and Inari, 1742-1886], Studia Historica Septentrionalia 47 (Rovaniemi: Pohjois-Suomen Historiallinen Yhdistys, 2005), 392-416.

20 Lehtola (2012), 409-15; Nyyssönen (2014b), 70-72.

21 E.g. Jukka Nyyssönen, "Everybody Recognized That We Were Not White:" Sami Identity Politics in Finland, 1945-1990 (Tromsø: Diss. University of Tromsø, 2007), 233-34.

22 Veli-Pekka Lehtola, Saamelaisten parlamentti, Suomen saamelaisvaltuuskunta 1973-1995 ja Saamelaiskäräjät 1996-2003 [The Parliament of the Sámi, Sámi Delegation 1973-1995 and the Sámi Parliament 1996-2003] (Inari: Saamelaiskäräjät, 2005b), 76ff., 106ff.

23 Nyyssönen (2014a), 171.

24 Nyyssönen (2014b), 78-81. 
Unlike many other areas of Sámi ethnopolitical activity, real achievements are to be found in the issue of education: in 1985, school legislation secured the right to benefit from teaching in and on the Sámi language. The education plan still emphasised the sustainment of the Finnish identity and Finnish culture, while Sámi culture went unmentioned. The position of Sámi as a language of instruction was further fortified between 1991 and 1995, when its right to be taught as an independent mother tongue was recognised. In 1994, a new teaching plan for comprehensive schools acknowledged the Sámi as an indigenous people and the right of the children to grow into members of the Sámi society and the Finnish society. In 1998, a first mention of an obligation to arrange teaching in Sámi in schools in the Sámi home area to pupils with a command of Sámi was articulated, whereas only in 2006 was multiculturalism mentioned for the first time. ${ }^{25}$

These are to date the greatest ethnopolitical achievements that the Sámi can point to in a Finnish context. The reasons for their success are that victory has been reached in a 'soft' interest area, with less at stake for other local actors, the rights of which the state has an obligation to protect. Another reason is that the Sámi curriculum has not been substituted for the Finnish curriculum: achievements in the field of Sámi teaching have taken place within the Finnish educational structure, but have never been allowed to replace it. At a state level, the protection of Sámi culture has long enjoyed a positive resonance and, more importantly, there is less at stake for the state than, for example, in the issue of land ownership. Owing to particular conditions of linguistic kinship between the Sámi and Finnish languages, Sami language issues receive support in Finland in a different manner than is the case in Scandinavian countries. ${ }^{26}$

As improvements were made to the legislation and structures were put in place in schools to provide education in and on the Sámi languages, the struggle to maintain these rights entered the schools themselves. Teaching in and on Sámi languages has constantly had to defend its share of the education given and its presence in education plans, as well as having to tackle a lack of initiative by the rest of the staff. This concerns schools within the Sámi home area: one issue that remains is the insufficient right of the 70 per cent of Sámi pupils who live outside the Sámi home area to an education in a Sámi language. This discourse has not become less urgent, or less pressing either; the aim is to mobilise the whole Sámi community to sustain the various Sámi languages and the politics of this issue has reached numerous personal and private spheres. ${ }^{27}$ This ethos of continuing this struggle for survival has marked research on the subject as well, and I shall return to this later in the article.

25 Ulla Aikio-Puoskari, Raportti saamelaisopetuksesta Pohjoismaiden peruskouluissa: Pohjoismainen vertailu opetuksen perusedelletysten näkökulmasta [A report on Sámi tuition in state schools in the Nordic countries: a Nordic comparison from the point of view of basic tuition requirements] (Inari: Saamelainen Parlamentaarinen Neuvosto, 2006), 12-13; Lehtola (2005b), $107 \mathrm{ff}$.

26 Jukka Nyyssönen, "Principles and Practice in Finnish Policies towards the Sámi People," in First World, First Nations: Internal Colonialism and Indigenous Self-Determination in Northern Europe and Australia, ed. Günter Minnerup and Pia Solberg (Eastbourne: Sussex Academic Press, 2011), 89.

27 Aikio-Puoskari (2006), 113; Nyyssönen (2014a), 168-69; Rauna Rahko-Ravantti, Saamelaisopetus Suomessa: Tutkimus saamalaisopettajien opetustyöstä suomalaiskouluissa [Sámi tuition in Finland: a study of the tuition provided by Sámi teachers in Finnish schools] (Rovaniemi: Acta Universitatis Lapponiensis 332, 2016), 66ff., 103ff. 
The most recent research depicts the current situation concerning education in and on Sámi as being still framed by "Finnish" elements. Taking Sámi parameters as a starting-point in teaching is still experienced as difficult and is dependent on the initiative of Sámi teachers. Schools have had to take on much of the responsibility for teaching the pupils a Sámi language, and that of teaching Sámi handicrafts still lies with individual teachers. The autonomy and room for proactive agency on the part of Sámi teachers is still considered to be smaller, by comparison with that of Finnish teachers. ${ }^{28}$

\section{The school experience and narratives of assimilation}

So much for actual school history. Before we embark on the kinds of narratives this has generated in research, a word about the institutional setting in which they have been produced. Before the expansion of interest in Sámi studies in the early 2000s, research interest in the northern histories was concentrated in the northern universities of Finland: the Universities of Oulu and Lapland. In the former case, this appeared in the form of 'purely' historically scientific studies, rather than instrumental or aiming for implementation. At the University of Lapland, these studies were undertaken in the department of Education.

In this field of research the dominant narrative has been one of assimilation. The origins of this narrative can be traced to a seminal linguistic-sociological work on the issue by Marjut Aikio, Saamelaiset kielenvaihdon kierteessä [The Sámi in the thread of language shift], which documented in great detail the linguistic assimilation, the de facto language change, that took place in much of the Sámi home area after the Second World War because of the policies followed in the school institution. ${ }^{29}$ This work was widely referred to and resulted in a considerable focus on linguistic assimilation when the school institution became a focus of research. It became typical to describe schools as "fortresses of Finnicisation" and a lot of focus was devoted to the varying linguistic abilities and teachers with a command of Sámi languages. ${ }^{30}$

The catechist teaching is one debated issue of Sámi school history in Finland and its study is tricky: the success in providing a good education and achieving good results may be interpreted as an imposed cultural loss, and the efforts of people with good intentions as being harmful to the Sámi pupils. Esko I. Kähkönen balanced this problem by referring to plans to teach in Sámi, the existing literature in Sámi used in teaching, and Sámi pupils who already had a command of the Finnish language in a slightly apologetic manner. Kähkönen also demonstrated the difficulty of producing a coherent narrative of a history with numerous changes in policy between an emphasis on the use of Finnish or Sámi languages, with various actors and no lack of good intentions in providing pupils with an education in Sámi. Kähkönen claimed

28 Rahko-Ravantti (2016), 95ff.

29 Marjut Aikio, Saamelaiset kielenvaidon kierteessä: Kielisosiologinen tutkimus viiden saamelaiskylän kielenvaihdosta 1910-1980 [The Sámi in the thread of language shift: Language sociological study of the language change in five Sámi villages 1910-1980] (Helsinki: SKS, 1988), passim.

30 Veli-Pekka Lehtola, "Petsamon kolttasaamelaiset [The Skolt Sámi of Petsamo]," in Turjanmeren maa, Petsamon historia 1920-1944 [The land of Kola Ocean: History of Petsamo, 1920-1944], ed. Jouko Vahtola and Samuli Onnela (Rovaniemi: Petsamo-Seura, 1999), passim; Nyyssönen (2007), 117-19; Hilkka Rahkola, "Petsamon kansakoulut [The folk schools in Petsamo]", in Turjanmeren maa: Petsamon historia 1920-1944, ed. Jouko Vahtola and Samuli Onnela (Rovaniemi: PetsamoSeura, 1999), passim. 
that Lutheran principles contributed to the fact that Sámi was used as a language of instruction in many catechist schools during the early part of the twentieth century in northern Finland. Kähkönen constructed his narrative in a positive manner, depicting the catechists as bearers of Sámi as a language through their teaching, and as language instructors of the written material published in Sámi during the nineteenth century. Kähkönen himself, as well as many of the actors he presented, stressed the inherent right to a mother tongue among the Sámi and denied the claims of assimilative aims on the basis of legislation (identified as acts of goodwill), but in the end Kähkönen could not deny the gradual erosion in the command of Sámi languages, even in Utsjoki, a municipality with a Sámi majority. The early twentieth century was a period of erosion of education in Sámi as well, due for example to a hardening of Finnish nationalist opinion; Kähkönen's narrative ends by pointing to the well-meaning catechists operating in an increasingly hostile environment, while "holding the door open to their own (Sámi) culture." 31

In her doctoral thesis on the church and priests in the Sámi home area during the eighteenth and nineteenth centuries, Ritva Kylli writes contrary to the common perception that catechist teaching would have been the best-suited form of education, given the conditions in Lapland. Instead, she relies on contemporaneous sources and depicts an institution in constant trouble, due to the low number of teachers in the vast geographical area that the catechists were meant to serve. Kylli strongly questions the language of education used: many priests demanded that Finnish be used and education in Christianity took place with the help of Finnish literature. Kylli concludes that it is likely that the catechists used both languages in their teaching, but the language barrier was among the factors that resulted in poor learning results. The education provided was of a low quality and the conditions in which it was provided were inadequate, and criticised as such by contemporaneous teachers. ${ }^{32}$

The texts of Kähkönen and Kylli, especially the latter, may be taken to be genetic narratives, interested in historical developments and change per se. The texts are thematically framed by questions of the language of instruction and of the linguistic assimilation which serves as the looming end-product of the narrative formed around the institutional history. This is more evident in Kähkönen, who has some trouble to fitting the end-product to his apologetic tendency to explain away the policies, whereas Kylli merely charts the numerous historical changes in the education language policies. The complexity of the historical process and the emerging genetic narrative, as revealed by Kylli, render a construction of any linear narrative a difficult task.

In historical research of later periods of school history, assimilation remains an element in the narrative strategy, as the actual linguistic change became more pressing in the Sámi home area during the twentieth century. Veli-Pekka Lehtola has depicted a school institution striving to become a culturally sensitive institution but failing to do so, due to a lack of governmental effort and the poor allocation of human resources with a command of Sámi languages. ${ }^{33}$ In an earlier work I have credited catechist teaching with the potential for creating room to sustain a command of Sámi

31 Esko I. Kähkönen, Katekeetat Suomen Lapissa 200 vuotta [200 years of cathecists in Finnish Lapland] (Rovaniemi: Lapin korkeakoulun kasvatustieteellisiä julkaisuja A 4, 1988), 245-51, 262-92.

32 Kylli (2005), 337 ff.

33 Lehtola (2012), 95-99. 
languages and less assimilative pressure, since the teaching given to pupils was short in duration and the teachers had, in some cases, a command of Sámi languages. ${ }^{34}$ The narratives here are genetic ones of assimilation, the differences concerning only the level or depth of the actual assimilation. Whether the catechist institution was culture-preserving or assimilative remains an open issue in the field.

Assimilation has also been approached from the perspective of school policies, and whether there was a similar assimilative intention to that which existed in Norway and Sweden. This is another debated theme in Finnish school history. On previous occasions I have indicated that in the public sphere there was no such direct pressure towards cultural change, as there was in Norway, and that the assimilation which took place could be compared to that in the county of Nordland in Norway, labelled "unintentional" due to a lack of programmatic assimilation policy, as well as being due to Nordland's location outside the targeted areas, which were the coastal areas of Finnmark and Troms. In Finland, the public sphere was generally more "Sámi-friendly" than in Scandinavian countries. ${ }^{35}$

The sources produced at the middle level of administration have revealed another kind of discourse. Veli-Pekka Lehtola is a proponent of a darker narrative, where the social evolutionist discourse of a "dying people," the silencing of the special cultural needs of the Sámi and the inactivity of the officials responsible for fulfilling the well-meaning existing measures to provide Sámi pupils with an education in Sámi resulted in linguistic assimilation and colonisation. Efforts to introduce Sámi as a language of instruction suffered from active resistance from within the Sámi communities (who wanted tuition in Finnish) and from state officials (who referred eagerly to the same desire). As the few Sámi teachers became early advocates of Sámi issues, as well as part of the civilised elite in the Sámi home area, there were no positions available for them to work and promote their cause in the home region and in their native language, due to the inactivity of state officials, which deepened the linguistic assimilation..$^{36}$ Otso Kortekangas has shown that among provincial school officials there was a lower willingness to fulfill the latent requirements in the legislation providing a Sámi education in Sámi, and even a readiness to assimilative measures. ${ }^{37}$

In summary, assimilation is the end-product of the narrative span in studies of history. The narrative has grown more critical with regard to the history of the school institution and school legislation in Finland. This narrative is detectable in charting the lack of will to implement the potential of the legislation, a typical approach in Finnish educational policies long into the twentieth century. The focus on and voice given to the Sámi actors, who pushed for change without success, adds to the critical tone. This narrative of unfulfilled rights, of Sámi aspiration as well as Finnish goodwill and intentions that did not materialise, sometimes written in a frustrated and ironic tone, contains emancipationist and future-oriented aspects in the criticism it poses to state policies ${ }^{38}$ and indicating a turn towards critical narratives.

34 Nyyssönen (2007), 117-119.

35 Nyyssönen (2007), 83, 93; Nyyssönen (2011), 117-19.

36 Lehtola (2012), 94, 290-97; Veli-Pekka Lehtola, "Sámi Histories, Colonialism, and Finland," Arctic Anthropology 52, no. 2 (2015), 25-30 et passim.

37 Otso Kortekangas, "En nationell nödvändighet för allas bästa: Utbildningsauktoriteternas diskurser om assimilering genom utbildning av ursprungsbefolkningarna i tidigt 1900-tals Finland och Peru i ett jämförande perspektiv" (Pro gradu dissertation, Åbo Akademi, 2013), 67.

38 Kortekangas (2017), 125ff; Lehtola (2012), 86-94, 290-97. 


\section{Narratives in studies on Sámi pedagogy}

Educationalists, too, have produced narratives about assimilation. Institutionally, most of these studies have been produced in (and sometimes in cooperation between) young universities and institutions geared towards Sámi studies: the Sámi allaskuvla (Sámi University of Applied Sciences) in Kautokeino; the Giellagas Institute at the University of Oulu; and the University of Lapland in Rovaniemi. Other university institutions which concentrate on the issues of indigenous peoples are also represented in the sample. Paradigmatically, this vein of study belongs to the sphere of Sámi studies, with the aim of knowledge production for the Sámi cause and the improvement of their living conditions. ${ }^{39}$ The studies have instrumental and future-oriented aspects; they aim at reconciliation and decolonisation, as well as revealing hidden narratives and troubled memories. The research has a strong instrumental side, which is intended to improve existing school structures and heal those who have gone through the school experience. The narrative is one of assimilation here as well, but instead of being an end-product, assimilation is taken as the starting-point, being the historical injustice to be corrected. Studies on a lack of cultural sensitivity and the lack of teaching in and on the Sámi thus have a challenging and empowering tone. ${ }^{40}$ The latest example of this is provided by Rauna Rahko-Ravantti and her study is used here to show the continuing success of the assimilation narrative: according to Rahko-Ravantti, the school has had a twofold significance for the Sámi: 1) cultural and linguistic assimilation and a weakening of contacts with the Sámi culture, and 2) possibilities for improvement in personal incomes. ${ }^{41}$

Unlike historians, Sámi educationalists have adopted a decolonising angle in their studies of the school institution, school history and school experiences among Sámi pupils. This has deepened the critical narratives produced in pedagogical research. The assimilative wrongs of the past are corrected by action to promote healing in the schools through decolonisation and by indigenising the teaching. This research vein and focus has engaged many scholars: Irja Seurujärvi-Kari has studied the Sámi movement's engagement in the struggle against linguistic assimilation, having herself had a long career in the international Indigenous People's movement. ${ }^{42}$ Rauna Rahko-Ravantti constructs a critical narrative from assimilation/colonisation to decolonisation and linking the Sámi teaching to the indigenous discourse and pedagogies. ${ }^{43}$ Pigga Keskitalo has studied ways of building indigenous institutions (of education, etc.) from the practices and values of the peoples themselves. What all of these studies share is an aim to get rid of the external, colonial structures and implement their own cultural models in the modern structures through self-determination in educational issues. The assimilation frames the narrative and gives it both a

39 Jukka Nyyssönen and Veli-Pekka Lehtola, "Introduction: From Depictions of Race to Revitalizing a People-Aspects of Research on the Sámi in Finland and Norway," Arctic and North, no. 27 (2017), 51-56.

40 E.g. Aikio-Puoskari (2006), passim.

41 Rahko-Ravantti (2016), 15-17.

42 Irja Seurujärvi-Kari, Ale jaskot eatnigiella: Alkuperäiskansaliikkeen ja saamen kielen merkitys saamelaisten identiteetille [Don't silence the mother tongue: The significance of the Indigenous Peoples Movement and the Sámi language to the identity of the Sámi.] (Helsinki: Diss. University of Helsinki, 2012), passim.

43 Rahko-Ravantti (2016), passim. 
substance and a starting-point, which then has to be got rid of. ${ }^{44}$ The effortless future orientation in Pedagogy provides a better platform on which to construct critical narratives, since the temporary frames, including the future, examined in critical narratives and the quest of policy suggestions are available in its disciplinary toolbox, whereas History is not as well-equipped to achieve this.

This inherent 'lack' in history is less evident in multi-disciplinary studies of dormitory histories which have emerged recently. ${ }^{45}$ The internationally late emergence of this research interest has revealed dark histories and experiences. While researchers have taken heed of the multiplicity of the dormitory experience-it might have been socialising, bearable, even fun-the stress is on the negative and traumatising elements. According to many witnesses, the dormitories were places of fear, bullying and abuse; members of staff were considered emotionally cold and the dormitories were understaffed. The narrative of trauma is detectable, and the stress on cultural loss, due to the breaks in inter-generational communication and the Finnish language used in the dormitories, connects the genre to the narrative of assimilation as well. This genre has traits of a genetic narrative, in which histories are documented and revealed, but also a strong instrumental, future-oriented aspect, through the aim and desire to correct past wrongs materialising in the reconciliation commissions now active in Finland and in Norway.

From identity-political and ethnopolitical perspectives, the narrative of assimilation has been shown to possess many strengths. It has proven to possess great political and identificational potential within the Sámi community, building narratives that set the Sámi apart from the rest of the population. The narrative of assimilation has, for example, connected Sámi authors and scholars in Finland to the global discourse of the ongoing struggle of indigenous peoples against colonialism/imperialism and for decolonisation. Besides the gathering force that the victim identity provides for the Sámi, the identification and the narrative constructed legitimacy for Sámi access to the Indigenous People's movement in its early phases. The shared dormitory histories are part of the discursive process of post-colonising the Nordic states, which has received legitimacy in the Finnish public sphere as well, though only recently. This is a major breakthrough in the context of what is otherwise such a "good" state, as Finland has eagerly and traditionally envisioned itself. This posi-

44 Pigga Keskitalo, Saamelaiskoulun kulttuurisensitiivisyyttä etsimässä kasvatusantropologian keinoin [Searching for culturally sensitive Sámi schooling by means of educational anthropology] (Guovdageaidnu: Sámi Allaskuvla, Dieđut 1/2010), passim; Rahko-Ravantti (2016), passim.

45 Veli-Pekka Lehtola pioneered this genre in 1994: Veli-Pekka Lehtola, Saamelainen evakko: Rauhan kansa sodan jaloissa [Sámi evacuees: People of peace in conditions of war] (Helsinki: City-Sámit, 1994), 217-22; Anni-Siiri Länsman, "Saamelaislasten elämää 1960-luvun asuntolakoulussa - katkelmia ainekirjoitusvihkojen sivuilta [The life of Sámi children in the dormitory schools of the 1960s-excerpts from essay notebooks]," in Sámit, sánit, sátnehámit: Riepmočála Pekka Sammallahtii miessemánu 21. beaivve 2007 [The Sámi, words, wordings: Book dedicated to Pekka Sammallahti on 21st of May 2007], ed. Jussi Ylikoski and Ante Aikio (Helsinki: Suomalais-Ugrilaisen seuran toimituksia, 2007), passim; Bigga-Helena Magga, "Poropojat maailmalla: Tapaustutkimus koulun ja asuntolan vaikutuksesta porosaamelaisten perinteiseen elämänmuotoon [Reindeer boys out in the world: A case study on the impact of school and dormitory life on the traditional way of life of the reindeer Sámi]" (Pro gradu dissertation, Lapin yliopisto, 1997), passim; Minna Rasmus, Bággu vuolgit, bággu birget: Sámemánáid ceavzinstrategiijat Suoma álbmotskuvlla ásodagain 1950-1960-logus [Forced to go, forced to hold their own: The coping stragies of Sámi children in the folk school dormitories of the 1950s and 1960s] (Oulu: Publications of Giellagas Institute NR 10, 2008), passim. 
tive resonance is one of the most important features of the narrative and has led to tangible results. ${ }^{46}$

As the reigning narrative, some problems are evident. The narrative of assimilation is stingy with regard to elements of positive self-image. Dominant narratives tend to have a stunting effect on the variation of "usable" histories and a silencing effect on less dramatic historical experiences, as Sanna Valkonen has pointed out. ${ }^{47}$ The experience of and identification with histories/narratives of assimilation and colonisation are not necessarily shared by all the Sámi, although they have been turned into a political asset. In spite of the level of positive resonance, the narrative is still a vulnerable and contested one: it is articulated against truly dominant state discourses and it is contested on many occasions by referring to the ethnic blindness of trauma in the schools. This is denied by referring to the cultural component: it was on many occasions precisely the Sámi culture, language and ethnicity per se that was the cause of traumatising treatment. The school institution did not support the Sámi in the way that it supported Finnish culture and language. ${ }^{48}$

The scholarly production studied here has been published from the 1980 s onwards. The earlier studies, most obviously that of Marjut Aikio, were produced under what Veli-Pekka Lehtola and Anni-Siiri Länsman label the pre-institutionalised era of the Sámi movement, when an oppositional attitude towards the Finnish state was eagerly adopted by researchers and the imagery produced of the Sámi was mostly univocal and victimising. From about the 1990s onwards, various venues of Sámi activity, e.g. ethnopolitics (the Sámi Parliament) and research (the Giellagas Institute at the University of Oulu), were institutionalised. The Sámi movement dispersed into institutions of power administered from above and the field became multivocal and contested. These multiple venues have become more independent of one another, while local and national opposition has questioned their representations of Sáminess. Lehtola and Länsman claim that this multivocal dynamism is an aspect that researchers have found hard to reach. This may be the case, and the rather old-fashioned approach to studies of school histories proves it to some extent. ${ }^{49}$

\section{Conclusions: Conflicting narratives?}

The narrative of (linguistic) assimilation dominates this research field for good, historically verifiable reasons. A more sinister and distressing narrative of trauma dominates the dormitory histories and this narrative has truly shaken the foundations

46 Jukka Nyyssönen, "Sami Counter-Narratives of Colonial Finland: Articulation, Perception and the Boundaries of the Politically Possible," Acta Borealia 30, no. 1 (2013), 110ff.; Nyyssönen (2014b), 77-82.

47 Sanna Valkonen, Poliittinen saamelaisuus [Political Sámi-ness] (Tampere: Vastapaino, 2009), 29-33 et passim.

48 Pigga Keskitalo, Merja Paksuniemi, Jukka Nyyssönen, Inker-Anni Linkola, Tuija Turunen, and Leonie McIntosh, "Saamelaisten ja Australian alkuperäiskansojen kouluhistorian erityispiirteet [Special features of the school history of the Sámi and indigenous people of Australia]," Ennen ja nyt, 3/2016, http://www.ennenjanyt.net/2016/09/saamelaisten-ja-australian-alkuperaiskansojen-kouluhistorian-erityispiirteet/\#identifier_96_4037, accessed 31.10.2018.

49 Veli-Pekka Lehtola and Anni-Siiri Länsman, "Saamelaisliikkeen perintö ja institutionalisoitunut saamelaisuus [The heritage of the Sámi movement and institutionalised Sámi-ness]," in Saamenmaa: Kulttuuritieteellisiä näkökulmia [Sámiland: Perspectives from cultural sciences], ed. Veli-Pekka Lehtola, Ulla Piela and Hanna Snellman, Kalevalaseuran vuosikirja 91 (Helsinki: SKS, 2012), $22-32$. 
of the anti-imperial 'good' state of Finland. The function of much research and of the narrative strategy has been to bring to light the histories of assimilation and to correct them.

But what about the chasm between the critical narratives detected in Pedagogy research and the genetic narratives detected in History studies (to simplify the division a little)? This division has been created and sustained by differences in the research or history politics, and in disciplinary differences in the ethos concerning policy suggestions. Historians have based their studies on ample choice of archival sources, mostly correspondence and reports produced by the school officials, covering all the available levels of church and municipal/state administration responsible of the education. Educationalists have used oral sources, which has also had consequences on the politics of writing. The critical narrative has been produced in pedagogical research under the ethos of a continuing struggle concerning the status and the rights of Sámi pupils to education in their mother tongue, a position which it is necessary to sustain in conditions of still-insufficient rights and threatened languages. The aim of a hermeneutic understanding still influences much of the History research on the topic, while a more instrumental leaning has always been the rationale in Pedagogy. The institutional setting in which the narratives have been produced is another source of differing strategies. In much of the pedagogical research, institutions have an official task and an emancipationist mission to produce knowledge in the best interests of the Sámi pupils. Historians operating in the field of Sámi history have seldom expressed such aims. Having said this, in the realm of Sámi research, it is precisely the continuing emphasis on assimilation that might still create synergies between disciplines, the possibility of producing narratives which matter and which should be told and heard. The critical narrative of unfulfilled rights also indicates some readiness to air frustrations in History research.

Finally, I wish to present some reflections about future challenges and possibilities in researching Sámi school history. One of the challenges is to move beyond histories of assimilation towards agentic histories of contact (instead of conflict) and of pupils coping with new situations..$^{50}$ Even though mention is made of varied school experiences, the field lacks a more comprehensive grip on the school as a site of cultural negotiation, as a site of resistance, as a source of personal empowerment, embracing the resources offered by the institution, as well as agentic ways of disengaging from the national school policies on the part of the teachers. ${ }^{51}$ This should not and does not mean 'denying' histories of assimilation and cultural violence. Histories should not become apologetic, but truly multivocal. Histories of assimilation are part of the Sámi school histories, which have to be studied in their multiple contexts to discover the various impacts of the school experience at various times. In the future, the emphasis on multivocality might perhaps offer insights into the various pedagogical needs arising from the local communities. This should improve the possibility of correcting the tradition of assimilation, as well as better utilising the critical narrative. In other words, it should be possible to achieve much using a genetic narrative strategy both to understand historical complexity and to attribute agency to historical actors.

50 Lehtola (2005a), 93-94.

51 See e.g. Williamson (1997), 408-11. 


\section{References}

Ahonen, Sirkka and Jukka Rantala. "Introduction: Norden's Present to the World." In Nordic Lights: Education for Nation Civic Society in the Nordic Countries, 18502000, edited by Sirkka Ahonen and Jukka Rantala, 9-28. Studia Fennica. Historica 1. Helsinki: SKS, 2001.

Aikio, Marjut. Saamelaiset kielenvaidon kierteessä: Kielisosiologinen tutkimus viiden saamelaiskylän kielenvaihdosta 1910-1980 [The Sámi in the thread of language shift: Language sociological study of the language change in five Sámi villages 1910-1980]. Helsinki: SKS, 1988.

Aikio-Puoskari, Ulla. Raportti saamelaisopetuksesta Pohjoismaiden peruskouluissa: Pohjoismainen vertailu opetuksen perusedelletysten näkökulmasta [A report on Sámi tuition in state schools in the Nordic countries: A Nordic comparison from the point of view of basic tuition requirements]. Inari: Saamelainen Parlamentaarinen Neuvosto, 2006.

Gunaratnam, Yasmin. Researching Race and Ethnicity: Methods, Knowledge and Power. London: Sage Publications, 2003.

Heiret, Jan, Teemu Ryymin, and Svein Atle Skålevåg. "Innledning." In Fortalt fortid, Norsk historieskriving etter 1970, edited by Jan Heiret, Teemu Ryymin and Svein Atle Skålevåg, 7-34. Oslo: Pax Forlag, 2013.

Keskitalo, Pigga. Saamelaiskoulun kulttuurisensitiivisyyttä etsimässä kasvatusantropologian keinoin [Searching for culturally sensitive Sámi school by means of educational anthropology]. Dieđut 1/2010. Guovdageaidnu: Sámi Allaskuvla, 2010.

Keskitalo, Pigga, Veli-Pekka Lehtola, and Merja Paksuniemi. "Johdatus saamelaisten kansanopetuksen ja koulunkäynnin historiaan [An introduction to the history of Sámi education and school attendance]." In Saamelaisten kansanopetuksen ja koulunkäynnin historia Suomessa [The history of Sámi education and school attendance in Finland], edited by Pigga Keskitalo, Veli-Pekka Lehtola and Merja Paksuniemi, 13-28. Turku: Siirtolaisuusinstituutti, 2014.

Kettunen, Pauli and Hannu Simola, eds. Tiedon ja osaamisen Suomi: Kasvatus ja koulutus Suomessa 1960-luvulta 2000-luvulle [Finland of knowledge and know-how: Education and schooling in Finland from 1960s to 2000s]. Helsinki: SKS, 2012.

Kortekangas, Otso. "En nationell nödvändighet för allas bästa: Utbildningsauktoriteternas diskurser om assimilering genom utbildning av ursprungsbefolkningarna i tidigt 1900-tals Finland och Peru i ett jämförande perspektiv." Pro gradu dissertation, Åbo Akademi, 2013.

Kortekangas, Otso. Tools of Teaching and Means of Managing: Educational and Sociopolitical Functions of Languages of Instruction in Elementary Schools with Sámi Pupils in Sweden, Finland and Norway 1900-1940 in a Cross-National Perspective. Turku: Iloinen tiede, 2017.

Kylli, Ritva. Kirkon ja saamelaisten kohtaaminen Utsjoella ja Inarissa 1742-1886 [The encounter between the church and the Sámi in Utsjoki and Inari, 17421886]. Studia Historica Septentrionalia 47. Rovaniemi: Pohjois-Suomen Historiallinen Yhdistys, 2005.

Kylli, Ritva. "Utsjoen kristillinen kansanopetus Laiti-suvun edustajien kautta kuvattuna [The Christian education in Utsjoki depicted through Laiti-kin]." In Saamelaisten kansanopetuksen ja koulunkäynnin historia Suomessa, edited by Pigga Keskitalo, Veli-Pekka Lehtola and Merja Paksuniemi, 104-20. Turku: Siirtolaisuusinstituutti, 2014. 
Kähkönen, Esko I. Katekeetat Suomen Lapissa 200 vuotta [200 years of cathecists in Finnish Lapland]. Rovaniemi: Lapin korkeakoulun kasvatustieteellisiä julkaisuja A 4, 1988.

Lehtola, Veli-Pekka. Saamelainen evakko: Rauhan kansa sodan jaloissa [Sámi evacuees: People of peace in conditions of war]. Helsinki: City-Sámit, 1994.

Lehtola, Veli-Pekka. "Petsamon kolttasaamelaiset [The Skolt Sámi of Petsamo]." In Turjanmeren maa: Petsamon historia 1920-1944 [The land of Kola Ocean: History of Petsamo 1920-1944], edited by Jouko Vahtola and Samuli Onnela, 149-70. Rovaniemi: Petsamo-Seura, 1999.

Lehtola, Veli-Pekka. “'The Right to One’s Own Past:' Sámi Cultural Heritage and Historical Awareness." In The North Calotte: Perspectives on the Histories and Cultures of Northernmost Europe, edited by Maria Lähteenmäki and Päivi Pihlaja, 83-94. Publications of the Department of History 18. Helsinki/Inari: University of Helsinki, Kustannus-Puntsi, 2005a.

Lehtola, Veli-Pekka. Saamelaisten parlamentti: Suomen saamelaisvaltuuskunta 19731995 ja Saamelaiskäräjät 1996-2003 [The Parliament of the Sámi: Sámi delegation 1973-1995 and the Sámi parliament 1996-2003]. Inari: Saamelaiskäräjät, 2005b.

Lehtola, Veli-Pekka. Saamelaiset suomalaiset: Kohtaamisia 1896-1953 [The Sámi Finns: Encounters 1896-1953]. Helsinki: SKS, 2012.

Lehtola, Veli-Pekka. "Sámi Histories, Colonialism, and Finland." Arctic Anthropology 52, no. 2 (2015), 22-36.

Lehtola, Veli-Pekka and Anni-Siiri Länsman. "Saamelaisliikkeen perintö ja institutionalisoitunut saamelaisuus [The heritage of the Sámi movement and institutionalised Sámi-ness].” In Saamenmaa: Kulttuuritieteellisiä näkökulmia [Sámiland: Perspectives from cultural sciences], edited by Veli-Pekka Lehtola, Ulla Piela and Hanna Snellman, 13-35. Kalevalaseuran vuosikirja 91. Helsinki: SKS, 2012.

Länsman, Anni-Siiri. "Saamelaislasten elämää 1960-luvun asuntolakoulussa: Katkelmia ainekirjoitusvihkojen sivuilta [The life of Sámi children in the dormitory schools of the 1960s: Excerpts from essay notebooks]." In Sámit, sánit, sátnehámit: Riepmočála Pekka Sammallahtii miessemánu 21. beaivve 2007 [The Sámi, words, wordings: Book dedicated to Pekka Sammallahti on 21st of May 2007], edited by Jussi Ylikoski and Ante Aikio, 269-78. Helsinki: Suomalais-Ugrilaisen seuran toimituksia 253, 2007.

Magga, Bigga-Helena. "Poropojat maailmalla: Tapaustutkimus koulun ja asuntolan vaikutuksesta porosaamelaisten perinteiseen elämänmuotoon [Reindeer boys out in the world: A case study on the impact of school and dormitory life on the traditional way of life of the reindeer Sámi]." Pro gradu dissertation, Lapin yliopisto, 1997.

Meinander, Henrik. Suomen historia: Linjat, rakenteet, käännekohdat [The history of Finland: Lines, structures, turning points]. Helsinki: WSOY, 2006.

Nyyssönen, Jukka. "Everybody Recognized That We Were Not White:" Sami Identity Politics in Finland, 1945-1990. Tromsø: Diss. University of Tromsø, 2007.

Nyyssönen, Jukka. "Principles and Practice in Finnish Policies towards the Sámi People." In First World, First Nations: Internal Colonialism and Indigenous Self-Determination in Northern Europe and Australia, edited by Günter Minnerup and Pia Solberg, 80-96. Eastbourne: Sussex Academic Press, 2011. 
Nyyssönen, Jukka. "Sami Counter-Narratives of Colonial Finland: Articulation, Perception and the Boundaries of the Politically Possible." Acta Borealia 30, no. 1, (2013), 101-21.

Nyyssönen, Jukka. "Suomalainen koululaitos ja saamelaiskysymys [The Finnish school institution and the Sámi question]." In Saamelaisten kansanopetuksen ja koulunkäynnin historia Suomessa, edited by Pigga Keskitalo, Veli-Pekka Lehtola and Merja Paksuniemi, 154-74. Turku: Siirtolaisuusinstituutti, 2014a.

Nyyssönen, Jukka. "Saamelaisten kouluolot 1900-luvulla [Sámi school conditions in the twentieth century]." In Saamelaisten kansanopetuksen ja koulunkäynnin historia Suomessa, edited by Pigga Keskitalo, Veli-Pekka Lehtola and Merja Paksuniemi, 63-86. Turku: Siirtolaisuusinstituutti, 2014b.

Nyyssönen, Jukka and Veli-Pekka Lehtola. "Introduction: From Depictions of Race to Revitalizing a People-Aspects of Research on the Sámi in Finland and Norway." Arctic and North, no. 27 (2017), 50-62.

Rahkola, Hilkka. "Petsamon kansakoulut [The folk schools in Petsamo]." In Turjanmeren maa: Petsamon historia 1920-1944, edited by Jouko Vahtola and Samuli Onnela, 373-400. Rovaniemi: Petsamo-Seura, 1999.

Rahko-Ravantti, Rauna. Saamelaisopetus Suomessa: Tutkimus saamalaisopettajien opetustyöstä suomalaiskouluissa [Sámi tuition in Finland: A study of the tuition provided by Sámi teachers in Finnish schools]. Rovaniemi: Acta Universitatis Lapponiensis 332, 2016.

Rasmus, Minna. Bággu vuolgit, bággu birget: Sámemánáid ceavzinstrategiijat Suoma álbmotskuvlla ásodagain 1950-1960-logus [Forced to go, forced to hold their own: The coping stragies of Sámi children in the folk school dormitories of the 1950s and 1960s]. Oulu: Publications of Giellagas Institute NR 10, 2008.

Rüsen, Jörn. "Tradition: A Principle of Historical Sense-Generation and Its Logic and Effect in Historical Culture." History \& Theory 51, no. 4 (2012), 45-59.

Seurujärvi-Kari, Irja. Ale jaskot eatnigiella: Alkuperäiskansaliikkeen ja saamen kielen merkitys saamelaisten identiteetille [Don't silence the mother tongue: The significance of the Indigenous Peoples Movement and the Sámi language to the identity of the Sámi]. Helsinki: Diss. University of Helsinki, 2012.

Smith, Malinda S. "Situating Indigenous Education in Canada." In Essays on Transforming the Academy, Indigenous Education, Knowledge and Relations, edited by Smith Malinda S. Edmonton: University of Alberta, 2013.

Valkonen, Sanna. Poliittinen saamelaisuus [Political Sámi-ness]. Tampere: Vastapaino, 2009.

Waziyatawin (Angela Wilson). "Indigenous Knowledge, Anticolonialism and Empowerment." In Essays on Transforming the Academy, Indigenous Education, Knowledge and Relations, edited by Smith, Malinda S. Edmonton: University of Alberta, 2013.

Williamson, Alan. "Decolonizing Historiography of Colonial Education: Processes of Interaction in the Schooling of Torres Strait Islanders." International Journal of Qualitative Studies in Education 10, no. 4 (1997), 407-23. 


\section{Internet sources}

Keskitalo, Pigga, Merja Paksuniemi, Jukka Nyyssönen, Inker-Anni Linkola, Tuija Turunen, and Leonie McIntosh. "Saamelaisten ja Australian alkuperäiskansojen kouluhistorian erityispiirteet [Special features of the school history of the Sámi and indigenous people of Australia]." Ennen ja nyt 3/2016, http://www.ennenjanyt.net/2016/09/saamelaisten-ja-australian-alkuperaiskansojen-kouluhistorian-erityispiirteet/\#identifier_96_4037.

YLE Sápmi. “Äidinkielensä vuosikymmeniksi menettänyt Seija: 'Vasta viisikymppisenä päästin tuskan ulos sisältäni' [Seija lost her mother tongue for several decades: 'Only in my 50s could I let the pain out']." https://yle.fi/uutiset/3-9231306 (accessed October 16, 2016). 